\title{
PENGARUH KOMPENSASI, MOTIVASI DAN PELATIHAN KERJA TERHADAP KINERJA KARYAWAN ATAU PEGAWAI DINAS PERTANIAN DAERAH ISTIMEWA YOGYAKARTA
}

\author{
Abdul Rohman \\ Rohmana968@gmail.com \\ Universitas Ahmad Dahlan \\ Utik Bidayati \\ utikbidayati@yahoo.com \\ Universitas Ahmad Dahlan
}

\begin{abstract}
ABSTRAK
This study aims to determine whether compensation, motivation and job training affect the performance of employees or service employees Yogyakarta Special Region Agriculture and analyze the influential factors and has no effect on the performance of employees or employees of the Department of Agriculture Special Region of Yogyakarta. The sample in this study were employees or Dinas employees Yogyakarta Special Region of Agriculture. 84 samples were processed respondent. The sampling technique uses sampling purposive, the number of samples obtained was 84 respondents, i.e. sampling techniques with certain considerations. Considerations in this research is a permanent employee. Based on the results of statistical data analysis, the indicators of the study this is valid and the variables are reliable. Order individually from each of the most influential variables is the training variable work with a t test value of 3.758 , then compensation with a t test value of 2,309 . Then the variable that has no effect is the motivation variable with a t test value of -0.826 . Yogyakarta Special Region Government needs maintain elements that have been assessed as good as giving Work compensation and training, and those with less influence need to be evaluated back to work motivation. The amount of influence caused (R2) by these three variables together to the bound of 0.229 or $22.9 \%$, while the remaining 0.771 or $77.1 \%$ is influenced by other variables not examined in this study.
\end{abstract}

Keywords: compensation, motivation, job training, and performance the employee.

\footnotetext{
PENDAHULUAN

Pada masa sekarang ini, persaingan di antara perusahaan-perusahaan manufaktur semakin ketat. Maka perusahaan harus dapat berupaya untuk selalu meningkatkan kinerja yang efektif dan efisien. Agar dapat terus bertahan maka manajemen dalam suatu perusahaan harus dapat bekerja lebih efektif dan efisien. Pada kondisi perekonomian di era perdagangan bebas perusahaan juga dituntut untuk dapat memanfaatkan kemampuan yang ada semaksimal mungkin agar unggul dalam persaingan,
}

oleh karena itu perusahaan harus memiliki manajemen yang baik dan tangguh sehingga dapat melihat dan menggunakan peluang yang ada serta dapat mengidentifikasi masalah dan menyeleksi sert mengimplementasikannya dengan tepat.

Kompensasi diharapkan mampu memotivasi sehingga karyawan dapat menyelesaikan pekerjaannya dengan baik. Dengan adanya kompensasi yang memadai dan peningkatan motivasi yang dijalankan berhasil, maka seorang karyawan akan termotivasi dalam pelaksanaan pekerjaan 
yang dibebankan kepadanya dan berupaya mengatasi permasalahan yang terjadi.

Kinerja yang dicari oleh perusahaan juga tergantung pada motivasi karyawan. Menurut French dan Raven dalam Saputra (2010) motivasi adalah sesuatu yang mendorong seseorang untuk menunjukkan perilaku tertentu. Motivasionis the set of forces that cause people to be have incertain ways.

Pelatihan kerja juga tidak lepas ikut menjadi tumpuan untuk mewujudkan keberhasilan atas kinerja karyawan yang lebih baik dan efisien. Kinerja karyawan dalam suatu perusahaan sangatlah penting karena apabila kinerja karyawannya kurang baik, maka dapat dipastikan perusahaan tidak akan mampu bersaing dengan perusahaan lain.

Menurut Gomes (1995) pelatihan adalah setiap usaha untuk memperbaiki performansi pada suatu pekerjaan tertentu yang sedang menjadi tanggung jawabnya, atau satu pekerjaan yang ada kaitannya dengan pekerjaannya. Banyak organisasi yang mengabaikan persoalan kinerja jika persoalan tersebut tidak berarti, atau jika tidak ada solusi yang tampak langsung, maka kinerja karyawan tidak akan berjalan dengan baik. Supaya efektif, pelatihan biasanya harus mancangkup pengalaman belajar, aktivitas-aktivitas terencana dan didesain sebagai jawaban atas kebutuhankebutuhan yang berhasil. Secara ideal, pelatihan harus didesain untuk mewujudkan tujuan-tujuan organisasi, yang pada waktu yang bersamaan juga mewujudkan tujuan-tujuan dari para pekerja secara perorangan.

Ada beberapa faktor yang menyebabkan kinerja karyawan tinggi atau rendah, dalam hal ini perusahaan perlu menyediakan umpan balik yang bisa membantu organisasi dalam pengambilan keputusan yang akan berdampak pada kinerja perusahaan, semakin tinggi respon umpan balik yang dilakukan perusahaan akan semakin baik pula kinerja perusahaan tersebut. Tujuan dari penelitian ini di antaranya: 1) untuk mengetahui pengaruh signifikansi kompensasi terhadap kinerja karyawan, 2) untuk mengetahui pengaruh signifikansi motivasi terhadap kinerja karyawan, 3) untuk mengetahui pengaruh signifikansi pelatihan kerja terhadap kinerja karyawan dan 4) untuk mengetahui pengaruh kompensasi, motivasi dan pelatihan kerja secara bersama-sama terhadap kinerja karyawan.

\section{REVIEW LITERATUR DAN HIPOTESIS}

\section{Landasan Teori}

1. Kompensasi

Kompensasi merupakan balas jasa yang diberikan oleh perusahaan kepada para karyawannya yang dapat dinilai dengan uang dan mempunyai kecenderungan diberikan diberikan secara tetap (Nitisemito, 1982).

2. Motivasi

Motivasi adalah suatu proses dimana kebutuhan-kebutuhan mendorong seseorang untuk melakukan serangkaian kegiatan yang mengarah ketercapainya tujuan tertentu (Munandar, 2001).

\section{Pelatihan Kerja}

Menurut Gomes (1995) pelatihan kerja adalah setiap usaha untuk memperbaiki performansi pekerja pada suatu pekerjaan tertentu yang sedang menjadi tanggung jawabnya atau suatu pekerjaan yang ada kaitannya dengan pekerjaannya.

\section{Kinerja Karyawan}

Menurut Mangkunegara (2000) dalam bukunya manajemen sumber daya manusia perusahaan mengemukakan pengertian kinerja adalah hasil kerja secara kualitas dan kuantitas yang dicapai oleh seorang karyawan dalam melaksanakan tugasnya sesuai dengan tanggung jawab yang diberikan. 


\section{Penelitian Terdahulu}

1. Lathif (2012) dalam penelitiannya yang berjudul Pengaruh Pemberian Kompensasi Dan Motivasi Kerja Terhadap Kinerja Karyawan Di PT SAI Indonesia Cabang Yogyakarta, dimana hasil penelitiannya menunjukkan bahwa Pemberian Kompensasi dan Motivasi kerja berpengaruh signifikan terhadap kinerja karyawan PT SAI Indonesia Cabang Yogyakarta. Kesimpulan penelitiannya sebagai berikut:

a. Kompensasi berpengaruh signifikan terhadap kinerja karyawan PT SAI Indonesia Cabang Yogyakarta, dengan nilai statistik t hitung sebesar 2.292 dan $t$ tabel 2.021 nilai signifikansi sebesar 0,027.

b. Motivasi kerja berpengaruh signifikan terhadap kinerja karyawan PT SAI Indonesia Cabang Yogyakarta, dengan nilai statistik $\mathrm{t}$ hitung sebesar 2.958 dan $\mathrm{t}$ tabel 2.021 nilai signifikansi sebesar 0,005 .

c. Kompensasi dan Motivasi kerja secara bersama-sama berpengaruh signifikan terhadap kinerja karyawan PT SAI Indonesia Cabang Yogyakarta, dengan nilai statistik F hitung sebesar 7.455 dan $\mathrm{F}$ tabel 3,20 nilai signifikansi sebesar 0,002 .

2. Sartika (2014) dalam penelitiannya yang berjudul Pengaruh Pelatihan Kerja Dalam Meningkatkan Kinerja Karyawan Pada PT. PUSRI Pemasaran Daerah (PPD) Palembang, dimana hasil penelitiannya menunjukkan bahwa Pelatihan Kerja berpengaruh terhadap Kinerja Karyawan.

\section{Hipotesis}

H1: Ada pengaruh secara signifikan pemberian kompensasi terhadap kinerja karyawan.

$\mathrm{H} 2$ : Ada pengaruh secara signifikan motivasi kerja terhadap kinerja karyawan.
H3: Ada pengaruh secara signifikan pelatihan kerja terhadap kinerja karyawan.

H4: Ada pengaruh secara signifikan pemberian kompensasi, motivasi, dan pelatihan kerja secara simultan terhadap kinerja karyawan.

\section{METODE PENELITIAN}

\section{Populasi dan Sampel}

Populasi adalah wilayah generalisasi yaitu terdiri atas obyek/subyek yang mempunyai kualitas dan karakteristik tertentu yang diterapkan oleh peneliti untuk dipelajari dan kemudian ditarik kesimpulannya (Sugiyono, 2010). Populasi dalam penelitian ini adalah karyawan Dinas Pertanian Daerah Istimewa Yogyakarta.

Sampel adalah bagian dari jumlah dan karakteristik yang dimiliki oleh populasi tersebut (Sugiono, 2010). Penentuan sampel dilakukan dengan menggunakan purposive sampling, yaitu tenik penentuan sampel dengan pertimbangan tertentu (Sugiyono, 2010). Sampel pada penelitian ini adalah karyawan tetap, yaitu karyawan tetap bagian Subbag, Keuangan, Bidang Tanaman dan Pangan, Sarpras TP, Sekretariat, UPTD BPPTPH, UPTD BPSB, satpam dan Cleaning Service.

Kriteria pengambilan sampel dalam penelitian ini adalah seluruh karyawan yang bekerja di Dinas Pertanian Daerah Istimewa Yogyakarta. Jumlah pengambilan sampel dalam penelitian ini sebanyak 100 angket Kuesioner, adapun kuesioner yang kembali sebanyak 84 angket dan yang tidak kembali sebanyak 16 angket kuesioner.

\section{Definisi Operasional}

1. Variabel Independen

a. Kompensasi (X1)

Kompensasi merupakan balas jasa yang diberikan oleh perusahaan 
kepada para karyawannya yang dapat dinilai dengan uang dan mempunyai kecenderungan diberikan diberikan secara tetap (Nitisemito, 1982).

b. Motivasi (X2)

Motivasi adalah suatu proses dimana kebutuhan-kebutuhan mendorong seseorang untuk melakukan serangkaian kegiatan yang mengarah ketercapainya tujuan tertentu (Munandar, 2001).

c. Pelatihan Kerja (X3)

$$
\text { Menurut Gomes }
$$

pelatihan kerja adalah setiap usaha untuk memperbaiki performansi pekerja pada suatu pekerjaan tertentu yang sedang menjadi tanggung jawabnya atau suatu pekerjaan yang ada kaitannya dengan pekerjaannya.

2. Variabel Dependen

Variabel dependen (Y) yang digunakan dalam penelitian ini adalah kinerja karyawan. Menurut Mangkunegara (2000) dalam bukunya manajemen sumber daya manusia perusahaan mengemukakan pengertian kinerja adalah hasil kerja secara kualitas dan kuantitas yang dicapai oleh seorang karyawan dalam melaksanakan tugasnya sesuai dengan tanggung jawab yang diberikan.

\section{Uji Instrumen}

\section{Uji Validitas}

Uji validitas merupakan derajat ketepatan antara data yang terjadi pada obyek penelitian dengan daya yang dapat dilaporkan peneliti. Dengan demikian data yang valid adalah data yang tidak berbeda antara yang dilaporkan oleh peneliti dengan data yang sesungguhnya terjadi pada obyek peneliti. Bila peneliti membuat laporan yang tidak sesuai dengan apa yang terjadi pada obyek, maka data tersebut dapat dinyatakan tidak valid
(Sugiyono, 2008). Perhitungan dilakukan dengan menggunakan bantu SPSS 20. Adapun langkah-langkah sebagai berikut :

a. Menentukan kaidah pengambilan keputusan.

Jika $r$ hitung positif dan $r$ hitung $>r$ tabel maka data tersebut valid

Jika $r$ hitung tidak positif dan $r$ hitung $<\mathrm{r}$ tabel maka data tersebut tidak valid.

b. Membandingkan $\mathrm{r}$ hitung dengan $\mathrm{r}$ tabel. Tingkat signifikan 5\% dengan df $=$ jumlah kasus -2 .

c. Membuat kesimpulan.

\section{Uji Reliabilitas}

Reliabilitas berkenan dengan derajad konsistensi dan stabilitas data atau temuan. Dalam pandangan posivistik (kuantitatif), suatu data dinyatakan reliabel apabila dua atau lebih peneliti dalam obyek yang sama dalam waktu berbeda menghasilkan data yang sama, atau sekelompok data bila dipecah menjadi dua menunjukkan data yang tidak berbeda (Sugiyono, 2008).

Analisis ini menggunakan program SPSS 20, dengan alpha 0,6. Untuk menguji reliabilitas dalam pengujian ini adalah dengan membandingkan cronbach alpha pada hasil olahan SPSS dengan rule of thumb dari kesepakatan umum koefisian alpha yaitu lebih besar dari 0,6.

\section{Teknik Analisis Data}

1. Analisis Regresi Berganda

Analisis regresi linier berganda merupakan analisis data yang menghubungkan dua variabel atau lebih untuk mengetahui besarnya pengaruh dari perubahan variabel bebas terhadap variabel terikat dan dengan bantuan program SPSS 20. Dengan menggunakan analisis regresi linier berganda dapat diketahui pengaruh 
variabel independen kompensasi (X1), motivasi kerja (X2), pelatihan kerja (X3) terhadap variabel dependen yaitu kinerja karyawan (Y). Adapun rumus untuk menghitung regresi linier berganda adalah sebagai berikut:

$\mathrm{Y}=\mathrm{a}+\mathrm{b} 1 \mathrm{X} 1+\mathrm{b} 2 \mathrm{X} 2+\mathrm{b} 3 \mathrm{X} 3$

Dimana :

$\mathrm{Y}=$ Kinerja Karyawan

$\mathrm{a}=$ Konstanta

$\mathrm{b}=$ Koefisien regresi

$\mathrm{X} 1=$ Kompensasi

$\mathrm{X} 2=$ Motivasi

X3 = Pelatihan Kerja

\section{Uji Hipotesis}

1. Uji Parsial (Uji T)

Uji T digunakan untuk mengetahui hubungan masing-masing variabel independen. Jika nilai signifikansi < alpha sebesar 5\% atau 0,05, maka hipotesis nol ditolak dan hipotesis alternatif diterima. Sebaliknya, jika nilai signifikansi > alpha sebesar 5\% atau 0,05, maka hipotesis nol deterima dan hipotesis alternatif ditolak.

\section{Uji Simultan (Uji F)}

Pengujian ini dimaksudkan untuk mengetahui apakah kedua variabel tersebut bersama-sama mempunyai pengaruh signifikan dengan kinerja karyawan. Jika nilai signifikansi < alpha sebesar 5\% atau 0,05, maka hipotesis nol ditolak dan hipotesis alternatif diterima. Sebaliknya, jika nilai signifikansi > alpha sebesar 5\% atau 0,05, maka hipotesis nol diterima dan hipotesis alternatif ditolak.

\section{Uji Koefisien Determinasi}

Koefisien determinasi digunakan untuk mengetahui berapa persen (\%) besarnya pengaruh variabel independen terhadap variabel dependen. Semakin besar presentase koefisien determinasi maka pengaruh variabel independen terhadap variabel dependen semakin kuat dan sebaliknya.

\section{HASIL PENELITIAN DAN PEMBAHASAN}

\section{Hasil Analisis Responden}

Distribusi kuesioner

\begin{tabular}{|l|c|}
\hline Kuisoner yang disebar & 100 \\
\hline Kuesioner yang tidak kembali & 16 \\
\hline Kuesioner yang diterima & 84 \\
\hline Kuesioner yang sah & 84 \\
\hline Kuisoner yang tidak sah & 0 \\
\hline
\end{tabular}

Terlihat dalam tabel distribusi kuisoner yang diterima sebanyak 84 kuisoner, sedangkan kuesioner yang di sebar sebanyak 100 kuisoner, artinya ada 16 kuisoner yang tidak kembali. Dari tabel di atas menunjukkan jika kuesioner yang sah berjumlah 84 kuesioner dan kuesioner yang tidak sah ada 0 kuesioner.

Karakteristik Responden berdasarkan devisi atau

\begin{tabular}{|l|l|}
\hline Umum unit kerja \\
\hline Subbag kep. \& keuangan & 31 \\
\hline Bid.tanaman \& pangan & 4 \\
\hline Sarpras TP & 4 \\
\hline Sekretariat & 1 \\
\hline UPTD BPPTPH & 2 \\
\hline UPTD BPSB \&emasaran & 1 \\
\hline Pengelolaan \& & 10 \\
\hline hasil pertanian & 84 \\
\hline Bid. PPHP & 5 \\
\hline Tidak diketahui & 20 \\
\hline Jumlah & \\
\hline
\end{tabular}

Dari hasil klasifikasi berdasarkan devisi atau unit pekerjaan responden menunjukkan bahwa dibagian umum sebanyak 31 responden, subtansi bagian kepegawaian dan keuangan sebanyak 4 responden, bidang tanaman dan pangan sebanyak 4 responden, sarpres TP sebanyak 1 responden, sekretariat 
sebanyak 2 responden, UPTD BPPTPH sebanyak 10 responden, UPTD BPSB sebanyak 6 responden, pengelolaan dan pemasaran hasil pertanian sebanyak 1 responden, bidang PPHP sebanyak 5 responden dan yang tidak diketahui devisi atau unit kerjanya sebanyak 20 responden.

karakteristik responden berdasarkan jenis kelamin

\begin{tabular}{|l|l|}
\hline Pria & 28 responden \\
\hline Wanita & 30 responden \\
\hline Tidak diketahui & 26 responden \\
\hline Jumlah & 84 responden \\
\hline
\end{tabular}

Hasil klasifikasi berdasarkan jenis kelamin responden menunjukkan bahwa yang berjenis kelamin pria berjumlah 28 responden, yang berjenis wanita berjumlah 30 responden dan yang tidak diketahui jenis kelaminnya berjumlah 26 responden.

Karakteristik responden berdasrkan tingkat pendidikan

\begin{tabular}{|l|l|}
\hline SMA & 24 responden \\
\hline Perguruan tinggi & 29 responden \\
\hline Tidak di ketahui & 31 responden \\
\hline
\end{tabular}

Hasil klasifikasi berdasarkan tingkat pendidikan responden menunjukkan bahwa yang lulusan setingkat SLTA berjumlah 24 responden, yang berdasarkan kelulusan setingkat perguruan tinggi berjumlah 29 responden dan yang tidak diketahui responden setingkat SLTA ataupun setingkat perguruan tinggi berjumlah 31 responden.

Karakteristik responden berdasarkan usia

\begin{tabular}{|l|l|}
\hline $17 \mathrm{~s} / \mathrm{d} 24$ tahun & 2 responden \\
\hline $25 \mathrm{~s} / \mathrm{d} 34$ tahun & 7 responden \\
\hline $35 \mathrm{~s} / \mathrm{d} 44$ tahun & 16 responden \\
\hline $45 \mathrm{~s} / \mathrm{d} 54$ tahun & 39 responden \\
\hline $55 \mathrm{~s} / \mathrm{d} 64$ tahun & 6 responden \\
\hline Tidak di ketahui & 14 responden \\
\hline Jumlah & 84 responden \\
\hline
\end{tabular}

Hasil klasifikasi berdasarkan usia responden menunjukkan bahwa yang berusia di bawah 25 tahun berjumlah 2 responden, yang berusia antara $25 \mathrm{~s} / \mathrm{d}$ berusia 34 tahun 7 responden, yang berusia antara $35 \mathrm{~s} / \mathrm{d} \quad 44$ tahun 16 responden, yang berusia antara 45 s/d 54 tahun 39 responden, yang berusia antara 55 s/d 64 tahun 6 responden dan jumlah responden yang tidak diketahui usianya berjumlah 14 responden.

Karakteristik responden berdasarkan masa kerja

\begin{tabular}{|l|l|}
\hline 1 bulan s/d 1 tahun & 2 responden \\
\hline 1 tahun s/d 5 tahun & 10 responden \\
\hline 5 tahun s/d 10 tahun & 2 responden \\
\hline 10 tahun s/d 15 tahun & 4 responden \\
\hline 15 tahun s/d 20 tahun & 10 responden \\
\hline 20 tahun s/d 30 tahun & 34 responden \\
\hline 30 tahun s/d 40 tahun & 6 responden \\
\hline Tidak diketahui & 16 responden \\
\hline Jumlah & 84 responden \\
\hline
\end{tabular}

Hasil klasifikasi berdasarkan masa kerja responden menunjukan bahwa yang bekerja di bawah 1 tahun sebanyak 2 responden, yang bekerja di atas 1 tahun s/d 5 tahun sebanyak 10 responden, yang bekerja 5 tahun s/d 10 tahun sebanyak 2 responden, yang bekerja 10 tahun s/d 15 tahun sebanyak 4 responden, yang bekerja 16 tahun s/d 20 tahun sebanyak 10 responden, yang bekerja 20 tahun s/d 30 tahun sebanyak 34 responden, yang bekerja 30 tahun s/d 40 tahun. 


\section{Hasil Penelitian}

1. Hasil Uji Validitas

Rangkuman I Hasil Uji Validitas dengan tingkat level of significance 0,05

\begin{tabular}{|c|c|c|c|c|}
\hline Item & r-hitung & Posisi & r-tabel & Kesimpulan \\
\hline Kompensasi 1 & 0.627 & $>$ & 0.361 & Valid \\
\hline Kompensasi 2 & 0.705 & $>$ & 0.361 & Valid \\
\hline Kompensasi 3 & 0.570 & $>$ & 0.361 & Valid \\
\hline Kompensasi 4 & 0.781 & $>$ & 0.361 & Valid \\
\hline Kompensasi 5 & 0.759 & $>$ & 0.361 & Valid \\
\hline Kompensasi 6 & 0.778 & $>$ & 0.361 & Valid \\
\hline Kompensasi 7 & 0.527 & $>$ & 0.361 & Valid \\
\hline Kompensasi 8 & 0.696 & $>$ & 0.361 & Valid \\
\hline Kompensasi 9 & 0.684 & $>$ & 0.361 & Valid \\
\hline Motivasi 1 & 0.621 & $>$ & 0.361 & Valid \\
\hline
\end{tabular}

\begin{tabular}{|c|c|c|c|c|}
\hline Motivasi 2 & 0.674 & $>$ & 0.361 & Valid \\
\hline Motivasi 3 & 0.496 & $>$ & 0.361 & Valid \\
\hline Motivasi 4 & 0.787 & $>$ & 0.361 & Valid \\
\hline Motivasi 5 & 0.635 & $>$ & 0.361 & Valid \\
\hline Motivasi 6 & 0.723 & $>$ & 0.361 & Valid \\
\hline Motivasi 7 & 0.251 & $<$ & 0.361 & Tidak Valid \\
\hline Motivasi 8 & 0.766 & $>$ & 0.361 & Valid \\
\hline Motivasi 9 & 0.423 & $>$ & 0.361 & Valid \\
\hline Motivasi 10 & 0.054 & $<$ & 0.361 & Tidak Valid \\
\hline Pelatihan Kerja 1 & 0.162 & $<$ & 0.361 & Tidak Valid \\
\hline Pelatihan Kerja 2 & 0.437 & $>$ & 0.361 & Valid \\
\hline Pelatihan Kerja 3 & 0.214 & $<$ & 0.361 & Tidak Valid \\
\hline Pelatihan Kerja 4 & 0.311 & $<$ & 0.361 & Tidak Valid \\
\hline Pelatihan Kerja 5 & 0.545 & $>$ & 0.361 & Valid \\
\hline Pelatihan Kerja 6 & 0.666 & $>$ & 0.361 & Valid \\
\hline Pelatihan Kerja 7 & 0.258 & $<$ & 0.361 & Tidak Valid \\
\hline Pelatihan Kerja 8 & 0.717 & $>$ & 0.361 & Valid \\
\hline Pelatihan Kerja 9 & 0.655 & $>$ & 0.361 & Valid \\
\hline Pelatihan Kerja 10 & 0.587 & $>$ & 0.361 & Valid \\
\hline Pelatihan Kerja 11 & 0.508 & $>$ & 0.361 & Valid \\
\hline Kinerja 1 & 0.415 & $>$ & 0.361 & Valid \\
\hline Kinerja 2 & 0.305 & $<$ & 0.361 & Tidak Valid \\
\hline
\end{tabular}

\begin{tabular}{|c|c|c|c|c|}
\hline Kinerja 3 & 0.376 & $>$ & 0.361 & Valid \\
\hline Kinerja 4 & 0.810 & $>$ & 0.361 & Valid \\
\hline Kinerja 5 & 0.779 & $>$ & 0.361 & Valid \\
\hline Kinerja 6 & 0.810 & $>$ & 0.361 & Valid \\
\hline Kinerja 7 & 0.503 & $>$ & 0.361 & Valid \\
\hline Kinerja 8 & -0.003 & $<$ & 0.361 & Tidak Valid \\
\hline Kinerja 9 & - & $<$ & 0.361 & Tidak Valid \\
\hline Kinerja 10 & 0.183 & $<$ & 0.361 & Tidak Valid \\
\hline
\end{tabular}

Dari tabel di atas, dapat dilihat dari masing-masing item pertanyaan dari instrumen keempat Variabel Kompensasi (X1), Variabel Motivasi (X2), Variabel Pelatihan Kerja (X3), dan Kinerja Karyawan (Y): Pertama, memiliki nilai r-hitung > dari nilai kritis r-tabel. Kedua, memiliki nilai rhitung < dari nilai kritis r-tabel. Keduanya pada taraf signifikan $(\alpha=$ $5 \%$ dan df $=\mathrm{n}-2=30-2=28$ yang menunjukkan angka sebesar 0,361.

Hasil pengujian validitas yang dilakukan terdapat beberapa itemitem variabel yang tidak valid antara lain variabel Motivasi (X2) yaitu butir nomer 7 dan 10. variabel Pelatihan Kerja (X3) yaitu butir nomer 1,3,4 dan 7. variabel kinerja karyawan (Y) yaitu butir nomer 2,8,9 dan 10. Oleh sebab itu butir pertanyaan tersebut tidak bisa digunakan dalam pengumpulan data. Setelah butir-butir pertanyaan tersebut dihilangkan, kemudian diuji lagi, hasilnya seperti dalam tabel berikut: 
Rangkuman II Hasil Uji Validitas dengan tingkat level of significance 0,05

\begin{tabular}{|c|c|c|c|c|}
\hline Item & r-hitung & Posisi & r-tabel & Kesimpulan \\
\hline Kompensasi 1 & 0.627 & $>$ & 0,361 & Valid \\
\hline Kompensasi 2 & 0.705 & $>$ & 0,361 & Valid \\
\hline Kompensasi 3 & 0.570 & $>$ & 0,361 & Valid \\
\hline Kompensasi 4 & 0.781 & $>$ & 0,361 & Valid \\
\hline Kompensasi 5 & 0.759 & $>$ & 0,361 & Valid \\
\hline Kompensasi 6 & 0.778 & $>$ & 0,361 & Valid \\
\hline Kompensasi 7 & 0.527 & $>$ & 0,361 & Valid \\
\hline Kompensasi 8 & 0.696 & $>$ & 0,361 & Valid \\
\hline Kompensasi 9 & 0.684 & $>$ & 0,361 & Valid \\
\hline Motivasi 1 & 0.621 & $>$ & 0,361 & Valid \\
\hline Motivasi 2 & 0.674 & $>$ & 0,361 & Valid \\
\hline Motivasi 3 & 0.496 & $>$ & 0,361 & Valid \\
\hline Motivasi 4 & 0.787 & $>$ & 0,361 & Valid \\
\hline Motivasi 5 & 0.635 & $>$ & 0,361 & Valid \\
\hline Motivasi 6 & 0.723 & $>$ & 0,361 & Valid \\
\hline Motivasi 8 & 0.466 & $>$ & 0,361 & Valid \\
\hline Motivasi 9 & 0.423 & $>$ & 0,361 & Valid \\
\hline Pelatihan Kerja 2 & 0.437 & $>$ & 0,361 & Valid \\
\hline Pelatihan Kerja 5 & 0.545 & $>$ & 0,361 & Valid \\
\hline Pelatihan Kerja 6 & 0.666 & $>$ & 0,361 & Valid \\
\hline Pelatihan Kerja 8 & 0.717 & $>$ & 0,361 & Valid \\
\hline Pelatihan Kerja 9 & 0.655 & $>$ & 0,361 & Valid \\
\hline Pelatihan Kerja 10 & 0.587 & $>$ & 0,361 & Valid \\
\hline Pelatihan Kerja 11 & 0.508 & $>$ & 0,361 & Valid \\
\hline Kinerja 1 & 0.415 & $>$ & 0,361 & Valid \\
\hline Kinerja 3 & 0.376 & $>$ & 0,361 & Valid \\
\hline Kinerja 4 & 0.810 & $>$ & 0,361 & Valid \\
\hline Kinerja 5 & 0.779 & $>$ & 0,361 & Valid \\
\hline Kinerja 6 & 0.810 & $>$ & 0,361 & Valid \\
\hline Kinerja 7 & 0.503 & $>$ & 0,361 & Valid \\
\hline
\end{tabular}

Dari tabel di atas, hasil uji validitas yang telah dilakukan pada uji validitas yang pertama terdapat sepuluh item variabel yang tidak valid diantaranya variabel Motivasi (X2) yaitu butir nomer 7 dan 10. variabel Pelatihan Kerja (X3) yaitu butir nomer 1,3, 4 dan 7. variabel kinerja karyawan (Y) yaitu butir nomer 2,8,9 dan 10 . Setelah melakukan uji validitas yang kedua dari sembilan item variabel yang tidak valid tersebut dihilangkan, maka peneliti mendapatkan hasil pengujian validitas yang menunjukkan bahwa item variabel semuanya valid.

2. Hasil Uji Reliabilitas

Hasil Uji Reliabilitas

\begin{tabular}{|l|c|c|}
\hline \multicolumn{1}{|c|}{ Variabel } & Cronbach Alpha & Keterangan \\
\hline Kompensasi (X1) & 0,766 & Reliabel \\
\hline Motivasi (X2) & 0,757 & Reliabel \\
\hline Pelatihan Kerja (X3) & 0,702 & Reliabel \\
\hline Kinerja Karyawan (Y) & 0,752 & Reliabel \\
\hline
\end{tabular}

Dari tabel di atas dapat diketahui bahwa nilai Cronbach Alpha dari seluruh variabel yang diuji nilainya lebih besar dari 0,60, maka dapat disimpulkan bahwa seluruh variabel dalam penelitian ini lolos dalam uji reliabilitas dan dinyatakan reliabel yang berarti bahwa kuesioner yang digunakan dalam penelitian ini merupakan kuesioner yang handal.

3. Hasil Uji Regresi Linier Berganda

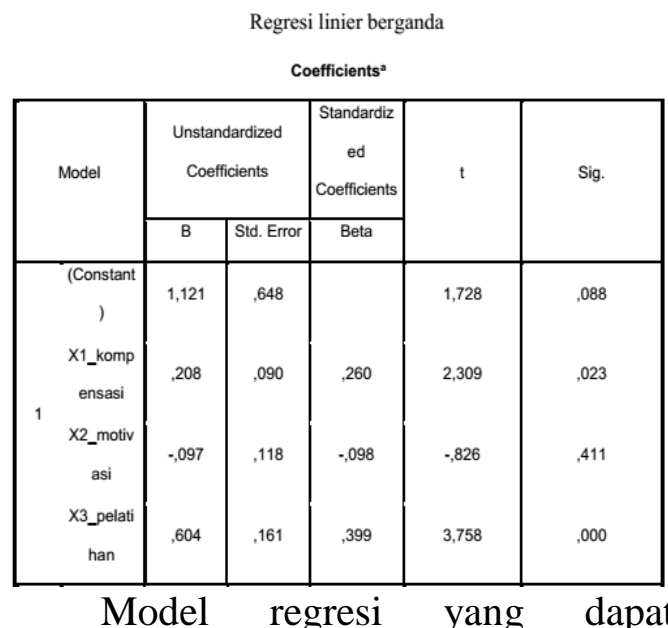
dituliskan dari hasil tersebut dalam bentuk persamaan regresi adalah sebagai berikut:

$\mathrm{Y}=\mathrm{a}+\mathrm{b} 1 \mathrm{X} 1+\mathrm{b} 2 \mathrm{X} 2+\mathrm{b} 3 \mathrm{X} 3$

$\mathrm{Y}=1,121+0,208 \mathrm{X} 1-0,097 \mathrm{X} 2+0,604 \mathrm{X} 3$

Dimana:

$\mathrm{Y}=$ kinerja karyawan

$\mathrm{a}=$ konstanta ( nilai intersep)

$\beta 1 \beta 2 \beta 3=$ koefisien regresi 
$\mathrm{X} 1=$ kompensasi

$\mathrm{X} 2$ = motivasi

$\mathrm{X} 3$ = pelatihan kerja

Adapun pengertian dari persamaan di atas dapat dijelaskan sebagai berikut:

Nilai $\alpha=1,121$ menunjukkan bahwa apabila variabel kompensasi, motivasi, pelatihan kerja bernilai nol atau tidak memiliki nilai, maka kinerja karyawan akan bernilai sebesar 1,121 dengan asumsi bahwa variabel-variabel lainnya tidak berubah.

Nilai $\beta 1=0,208$ menunjukkan bahwa setiap penambahan satu satuan kompensasi, maka akan menambah 0,208 satuan kinerja karyawan, dengan asumsi bahwa variabel-variabel lainnya tidak berubah.

Nilai $\beta 2=-0,097$ menunjukkan bahwa setiap penambahan satu satuan variabel motivasi, maka akan mengurangi kinerja yang sebesar 0,097 satuan kinerja karyawan, dengan asumsi bahwa variabel-variabel lainnya tidak berubah.

Nilai $\beta 3=0,604$ menunjukkan bahwa setiap penambahan satu satuan variabel pelatihan kerja, maka akan menambah 0,604 satuan kinerja karyawan, dengan asumsi bahwa variabel-variabel lainnya tidak berubah.

\section{Hasil Uji Parsial (Uji T)}

a. Variabel kompensasi (X1)

Hasil pengujian diperoleh nilai $\mathrm{t}$ untuk variabel kompensasi menunjukkan nilai $\mathrm{t}=2,309$ dengan nilai signifikansi sebesar $0,023<$ $0,05(\alpha)$. Dengan nilai signifikansi di bawah 0,05 tersebut menunjukkan bahwa kompensasi memiliki pengaruh yang signifikan terhadap kinerja karyawan (Y). Hal ini berarti hipotesis $\mathrm{Ha}$ diterima. Arah koefisien regresi positif memperjelaskan bahwa kompensasi memiliki pengaruh positif yang signifikan terhadap kinerja karyawan. Semakin baik kompensasi yang ada dalam perusahaan akan semakin tinggi pula kinerja karyawan, sebaliknya semakin tidak baik kompensasi yang ada dalam perusahaan semakin rendah pula kinerja karyawan.

b. Variabel motivasi (X2)

Hasil pengujian diperoleh nilai $\mathrm{t}$ untuk variabel motivasi menunjukkan nilai $\mathrm{t}=-, 826$ dengan nilai signifikansi sebesar 0,411 > $0,05(\alpha)$. Dengan nilai signifikansi di atas 0,05 tersebut menunjukkan bahwa motivasi tidak memiliki pengaruh yang signifikan terhadap kinerja karyawan (Y). Hal ini berarti hipotesis $\mathrm{Ha}$ ditolak dan H0 diterima. Arah koefisien regresi negatif memperjelaskan bahwa motivasi tidak memiliki pengaruh negatif yang signifikan terhadap kinerja karyawan. Hasil ini memberikan bukti empiris motivasi dari fisiologis, rasa aman, sosial, penghargaan dan aktualisasi diri tidak menentukan kinerja karyawan.

c. Variabel pelatihan kerja (X3)

Hasil pengujian diperoleh nilai $t$ untuk variabel pelatihan kerja menunjukkan nilai $\mathrm{t}=3,758$ dengan nilai signifikansi sebesar $0,000<$ $0,05(\alpha)$. Dengan nilai signifikansi di bawah 0,05 tersebut menunjukkan bahwa pelatihan kerja memiliki pengaruh yang signifikan terhadap kinerja karyawan. Hal ini berarti hipotesis Ha diterima.

Kesimpulannya adalah variabel kompensasi $\mathrm{X} 1$ dan variabel pelatihan kerja X3 memiliki pengaruh yang signifikan terhadap kinerja karyawan. Hasil pengujian variabel motivasi X2 menunjukkan bahwa motivasi tidak berpengaruh signifikan terhadap kinerja karyawan atau pegawai. 
5. Hasil Uji Simultan (Uji F)

Hasil analisis regresi secara bersama-sama ( simultan)

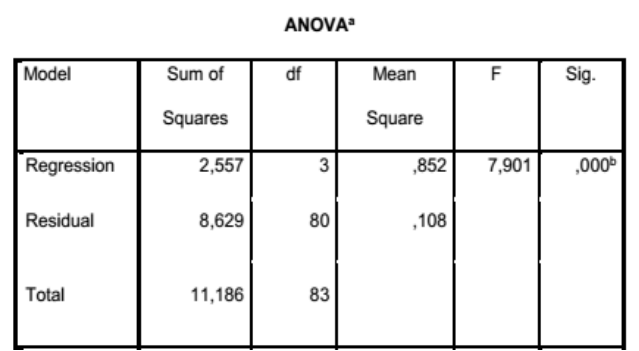

Nilai uji $\mathrm{F}$ menunjukkan angka signifikan sebesar 0,000 atau lebih kecil dari nilai alpha $5 \%(0,05)$ dan dapat disimpulkan bahwa secara bersamasama (simultan) variabel $\mathrm{X}$ berpengaruh terhadap variabel $\mathrm{Y}$ atau dalam hal ini hipotesis alternatif diterima.

\section{Hasil Uji Koefisien Determinasi}

Koefisien determinasi $\left(\mathrm{R}^{2}\right)$

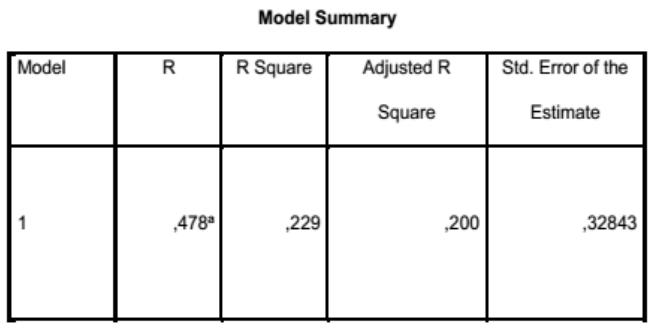

Hasil perhitungan regresi dapat diketahui bahwa koefisien determinasi (R2) yang diperoleh sebesar 0,229. Hal ini berarti $22,9 \%$ kinerja karyawan dipengaruhi oleh kompensasi, motivasi, dan pelatihan kerja. Sedangkan sisanya $77,1 \%$ kinerja karyawan dipengaruhi variabelvariabel lainnya yang tidak dibawa dalam penelitian ini.

\section{Pembahasan}

Secara umum penelitian ini menunjukkan hasil yang cukup baik. Hasil analisis deskriptif menunjukkan bahwa kompensasi yang diberikan oleh pemerintah secara umum sudah baik. Dari hasil tersebut selanjutnya diperoleh bahwa dari kedua variabel X (kompensasi dan pelatihan kerja) dan kedua variabelnya berpengaruh signifikan terhadap kinerja karyawan, yakni variabel kompensasi dan pelatihan kerja. Dan dari hasil yang ada, variabel motivasi X2 menunjukkan bahwa motivasi tidak berpengaruh secara signifikan terhadap kinerja karyawan atau pegawai.

Hasil penelitian menunjukkan bahwa variabel kompensasi memiliki pengaruh yang positif dan signifikan terhadap kinerja karyawan. Hasil ini memberikan bukti empiris kompensasi dari gaji pokok, penghasilan tidak tetap, tunjangan akan menentukan kinerja karyawan.

Hasil penelitian menunjukkan bahwa variabel motivasi tidak memiliki pengaruh yang signifikan terhadap kinerja karyawan. Hasil ini memberikan bukti empiris motivasi dari fisiologis, rasa aman, sosial, penghargaan dan aktualisasi diri perlu ditingkatkan dan dievaluasi kembali. Meminimalkan kesalahan perlu ditingkatkan guna untuk mendapatkan pengaruh yang signifikan terhadap kinerja karyawan atau pegawai.

Hasil penelitian menunjukkan bahwa variabel pelatihan kerja mempunyai pengaruh yang signifikan terhadap kinerja karyawan. Hasil ini memberikan bukti empiris bahwa pelatihan kerja berpengaruh yang signifikan terhadap kinerja karyawan.

\section{KESIMPULAN DAN SARAN}

\section{Kesimpulan}

1. Hasil analisis diperoleh bahwa variabel kompensasi (X1) memiliki koefisien regresi sebesar 0,208 (bertanda positif) terhadap kinerja karyawan (Y) dan nilai $\mathrm{t}$ hitung sebesar 2,309 dengan tingkat signifikan $0,023(<0,05)$. Hal ini berarti bahwa bukti kompensasi (X1) berpengaruh positif terhadap kinerja karyawan (Y). Dengan demikian hipotesis 1 yang menyatakan bahwa kompensasi (X1) berpengaruh positif terhadap kinerja karyawan (Y) dapat diterima. 
2. Hasil analisis diperoleh bahwa variabel motivasi (X2) memiliki koefisien regresi sebesar $-0,097$ (bertanda positif) terhadap kinerja karyawan (Y) dan nilai $t$ hitung sebesar $-0,826$ dengan tingkat signifikan 0,411 ( > 0,05). Hal ini berarti bahwa bukti motivasi (X2) berpengaruh negatif terhadap kinerja karyawan (Y). Namun tidak memiliki pengaruh yang signifikan terhadap kinerja karyawan. Maka dari itu, kipotesis X2 ditolak, karena nilai signifikansi probabilitas lebih besar dari pada 0,05, maka motivasi tidak memiliki pengaruh yang signifikan terhadap kinerja karyawan.

3. Hasil analisi diperoleh bahwa variabel pelatihan kerja (X3) memiliki koefisien regresi 0,604 (bertanda positif) terhadap kinerja karyawan (Y) dan nilai t hitung sebesar 3,758 dengan tingkat signifikan $0,000(<0,05)$. Hal ini berarti bahwa pelatihan kerja (X3) berpengaruh positif terhadap kinerja karyawan (Y). Dengan demikian Hipotesis X3 diterima, karena nilai signifikansi probabilitas lebih kecil dari pada 0,05 , maka pelatihan kerja memiliki pengaruh yang signifikan terhadap kinerja karyawan.

4. Hasil nilai uji $\mathrm{F}$ menunjukkan angka signifikan sebesar 0,000 atau lebih kecil dari nilai alpha 5\% $(0,05)$ dan dapat disimpulkan bahwa secara bersamasama (simultan) variabel $\mathrm{X}$ berpengaruh terhadap variabel $\mathrm{Y}$.

\section{Saran}

1. Saran Untuk PEMDA.

Berdasrkan kesimpulan yang diperoleh dalam penelitian ini, maka diajukan saran-saran sebagai pelengkap terhadap kompensasi, motivasi dan pelatihan kerja yang diberikan oleh PEMDA terhadap karyawan atau pegawai kantor.

a. Kompensasi
Kompensasi yang telah diberikan oleh PEMDA sudah cukup baik, maka peneliti menyarankan agar PEMDA lebih memperhatikan kompensasi yang diberikan karyawan atau pegawai Dinas Pertanian Daerah Istimewa Yogyakarta agar dalam bekerja lebih baik dan dapat menghasilkan target yang di inginkan.

b. Motivasi

Meskipun variabel motivasi
tidak berpengaruh signifikan
terhadap kinerja karyawan atau pegawai di Dinas Pertanian Daerah Istimewa Yogyakarta, sebaiknya PEMDA tetap lebih memotivasi pegawainnya agar karyawan atau pegawai lebih mempunyai sikap positif dalam bekerja. Sebab pada kondisi tertentu satu variabel tersebut dapat mempunyai pengaruh terhadap kinerja karyawan atau pegawai Dinas Pertanian Daerah Istimewa Yogyakarta.

c. Pelatihan kerja

Pelatihan kerja yang diberikan PEMDA sudah cukup baik, maka peneliti menyarankan agar PEMDA lebih memperhatikan pelatihan kerja yang diberikan karyawan atau pegawai Dinas Pertanian Daerah Istimewa Yogyakarta agar dalam bekerja lebih baik dan mengurangi kesalahan-kesalahan yang terjadi.

\section{Saran Untuk Penelitian Mendatang.}

Untuk penelitian yang akan datang disarankan untuk menambah variabel Independen lainnya selain kompensasi, motivasi dan pelatihan kerja. Kerena ketiga variabel ini hanya mempengaruhi tingkat kinerja karyawan sebesar $22,9 \%$ dan $77,1 \%$ lainnya dipengaruhi oleh variabel lain yang tidak dibawa dalam penelitian ini. Menambah veriabel penelitian adalah hal utama yang perlu dilakukan untuk penelitian selanjutnya, namun tentunya yang dapat mempengaruhi 
variabel Dependen kinerja karyawan misalnya kepemimpinan dan budaya organisasi agar lebih melengkapi penelitian ini kerena masih ada variabel-variabel Independen lain diluar penelitian ini yang mungkin bisa mempengaruhi kinerja karyawan.

\section{DAFTAR PUSTAKA}

Gomes, Faustino Cardoso. (1995).

Manajemen Sumber Daya Manusia.

Yogyakarta: Andi Offset.

Lathif. (2012). Pengaruh Pemberian

Kompensasi dan Motivasi Kerja

Terhadap Kinerja Karyawan. Skripsi.

Universitas Ahmad Dahlan

Yogyakarta.

Mangkunegara, Prabu Anwar A.A. (2000).

Manajemen Sumber Daya Manusia

Perusahaan. Bandung: PT Remaja

Rosda Karya.

Munandar, Ashar Sunyoto. (2001).

Psikologi Industri dan Organisasi.

Universitas Indonesia Jakarta.

Nitisemito, Alek S. (1982). Manajemen

Personalia. Jakarta: Ghalia

Indonesia.

Saputra. (2010). Pengaruh Kompensasi,

Kepuasan Kerja dan Motivasi Kerja

Terhadap Kinerja Karyawan. Skripsi.

Surabaya: Sekolah Tinggi Ilmu

Ekonomi Perbarnas.

Sartika. (2014). Pengaruh Pelatihan Kerja Dalam Meningkatkan Kinerja Karyawan Pada PT. Pusri Pemasaran Daerah (PPD). Skripsi. Palembang: Universitas Tridinanti.

Sugiyono. (2008). Metode Penelitian kuantitatif, Kualitatif dan $R \& D$. Edisi Keempat. Bandung: Alfabeta.

Sugiyono. (2010). Metode Penelitian Bisnis. Bandung: Alfabeta. 